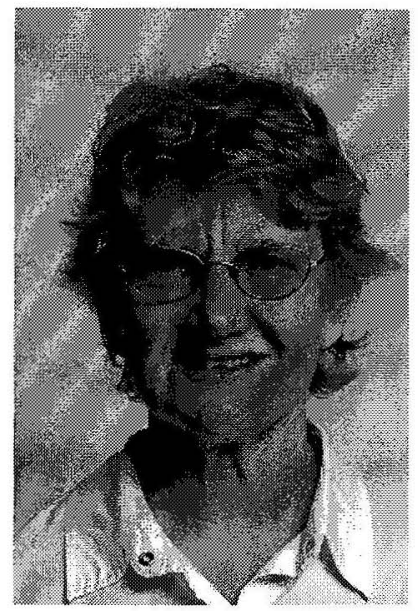

\title{
THE LABOUR MARKET \\ ACTIVITIES OF PEOPLE AGED 65 AND OVER
}

\author{
Julie Woolf \\ Statistics New Zealand
}

\begin{abstract}
This paper covers the labour market experiences of people aged 65 and over. Census data are used to examine broad trends in key labour market variables as well as giving a more detailed profile of the characteristics of the 2001 labour market for people in this age group. The paper also covers participation in unpaid work.
\end{abstract}

\section{Introduction}

\begin{abstract}
Almost half a million people were aged 65 plus at the time of the 2001 census. The population has doubled in the last 50 years and is expected to more than double again in the next 50 years, to reach $1,181,000$ by 2051 . However, the number of people aged 65 and over in employment has more than doubled since 1991, with 49,935 people in that age group in paid employment in 2001.
\end{abstract}

Changes to the Human Rights Act, outlawing compulsory retirement ages came into effect on 1 February 1999 and this has no doubt been a big influence on the increasing labour force participation rates for older people. Removal of surcharges on extra income earned while receiving National Superannuation will also have had an influence on labour market activity of this age group.

Other factors likely to encourage more older people to keep working include the encouragement that is being given to older people to have a positive attitude to life and to keep active and improvements in health treatments leading to better health outcomes.

\section{Employment Rates by Sex over time}

The employment rate (the proportion of the total population which is employed) has grown steadily since 1986 for people aged 65 and over. There was a slight dip between 1986 and 1991 when the rate went from 6 to 5.9 percent, but this was minor compared with the experiences of the younger population.

The effect of the downturn in the late 80's and early 90's was barely felt by older people in employment, whereas the employment rate of people aged 15-64 dropped by 7 percentage points between 1986 and 1991. Males were hit the hardest, dropping over 19 percentage points over the period, and as can be seen from the graph, they have never subsequently recovered to 1986 levels.

Between 1986 and 2001 the female employment rate for those aged 65 and over nearly trebled.

Although women accounted for the majority of the population aged 65 and over (56 percent) most of the employed were men ( 66 percent). The male/female employment balance has slowly been becoming more balanced, since 1986, when 74 percent of the older people who were employed were men. The imbalance probably reflects the lower expectations that women in these age groups had of employment in their lifetime. In the younger ages the male/female split is considerably more even (53 percent of employed people aged 15-64 were male in 2001) and as this group ages, it can be expected that there will be continued evening out of the male/female employment ratios for older people.

Older people have increased their share of total employment. In 1986 over 65's made up 1.4 percent of the employed, rising steadily to 2.9 percent in 2001 . For males the increase was from 1.7 percent to 3.6 percent of male employment, and for females 0.9 percent to 2.1 percent of female employment. 

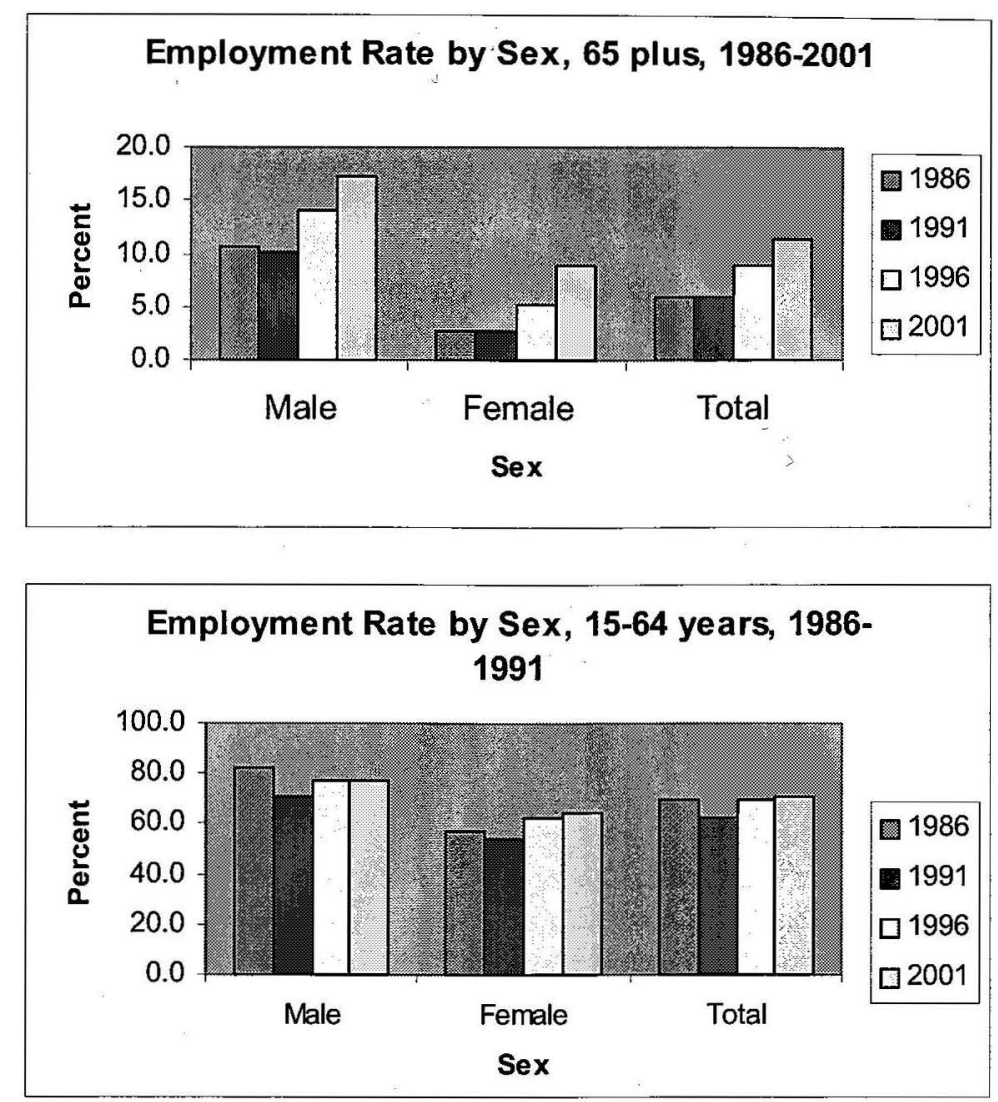

\section{Unemployment}

Overall unemployment not a big issue for this age group, with less than one thousand unemployed for each of the last four censuses. Unemployment rates have been very low since 1991 and the 1986 figure could be influenced by the way the questions on employment and unemployment were asked at that time.
Interestingly, these figures show that when unemployment among people aged 15-64 was peaking in the early 90 's unemployment for people aged 65 and over was low. This seems to suggest that older people have a flexible attitude to participation in the labour market, and exit when conditions are tight.

\begin{tabular}{|l|l|l|l|l|}
\hline \multicolumn{5}{|c|}{ Number Unemployed and Unemployment Rate } \\
\hline Year & 65 and over & Under 65 \\
\hline 1986 & 984 & $4.6 \%$ & 108,207 & $6.8 \%$ \\
\hline 1991 & 402 & $1.8 \%$ & 163,368 & $10.6 \%$ \\
\hline 1996 & 729 & $1.9 \%$ & 135,777 & $7.9 \%$ \\
\hline 2001 & 813 & $1.6 \%$ & 139,095 & $7.7 \%$ \\
\hline
\end{tabular}

\section{Employment by Sex and Age, 2001}

Employment levels drop as age increases, from 22 percent of 65-69 year olds employed, to 3 percent of those aged 85 or more.
Women are consistently less likely to be employed than men at all ages. Overall around 7 percent of women aged 65 and over are employed, compared to 17 percent of men.

Nearly one in three men and one in six women are in employment at age 65-69. 


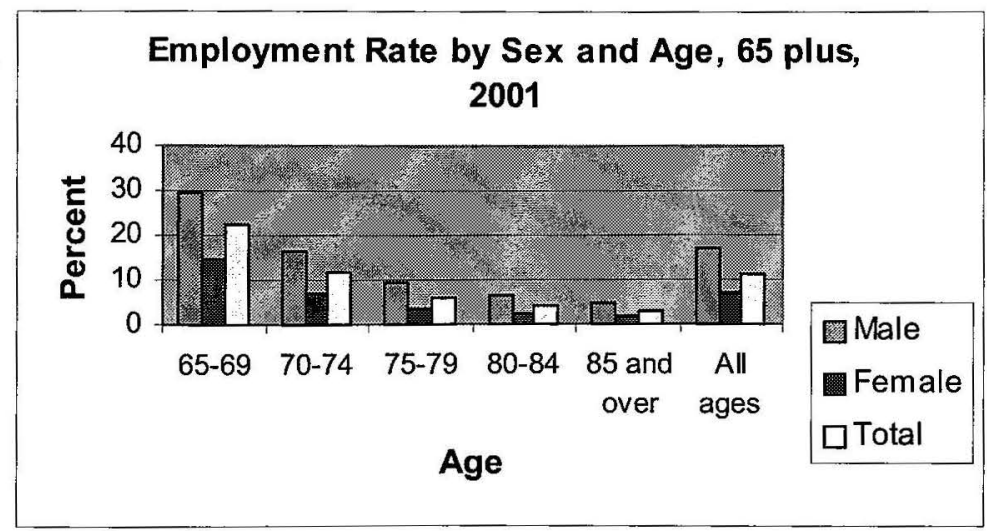

\section{Employment by Ethnicity}

Mäori aged 65 and over had the highest employment rate of people aged 65 years and over in 2001, at 14.8 percent or 3.3 percentage points higher than the next Ethnic group most likely to be in employment, European with an 11.8 percent employment rate. The employment rate for Pacific people was 8.2 percent and for Asian it was 8.2 percent.
The Survey of Older People in 2000 had a special sample of Mäori people aged 65-69 and included a question that asked whether the respondent had experienced redundancy in the ten years before they turned sixty. Around 18 percent of Mäori said they had experienced redundancy. Lack of funds to save for retirement during that period leading up to retirement may be a factor in the higher employment rate for Mäori, though later when occupations are discussed, the types of jobs Mäori do may also be a factor.

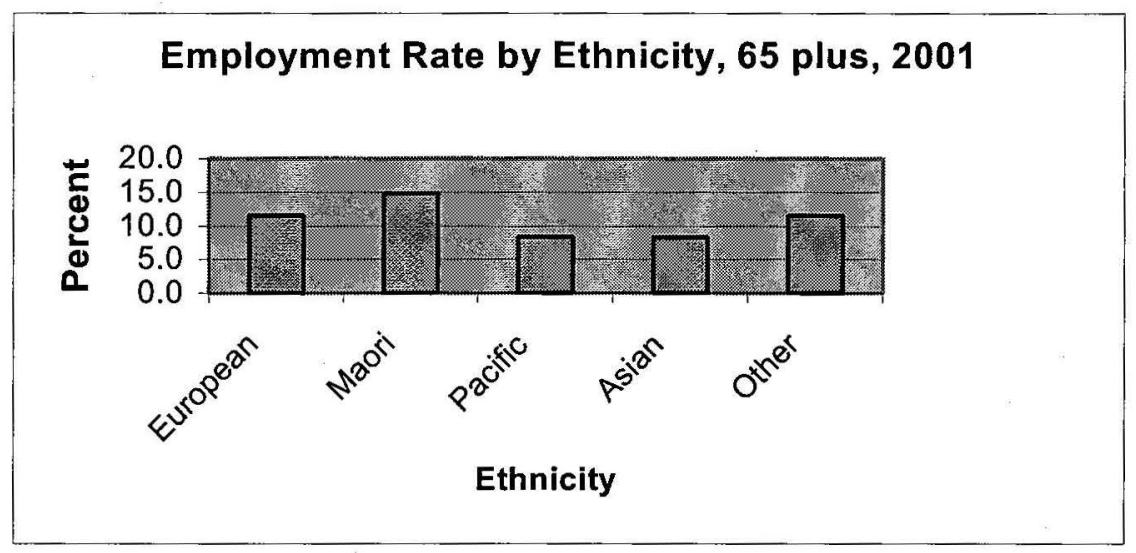

\section{Status in Employment}

People aged 65 and over in 2001 were just over twice as likely to be self-employed or an employer of others than their younger counterparts.

In 2001, 44.5 percent of employed persons 65 and over were self-employed or employers, compared to only 19.8 percent of workers aged 16-64. Older people are also more likely to be working unpaid in a family business or farm compared to younger people (13.6 percent versus 2.0 percent, respectively)
Just over half of employed males aged 65 and over and almost one third of employed older females are selfemployed/employer. Women are more likely to be employees.

Europeans and Asians are more likely to be working for themselves ( 45.7 and 40.5 percent respectively) but this work arrangement is much less common amongst Mäori and Pacific people (23.4 and 19.1 percent)

Flexibility is probably the reason why working as an employer or being self-employed in so popular with this age group. It allows working hours to be determined to suit, for example. 

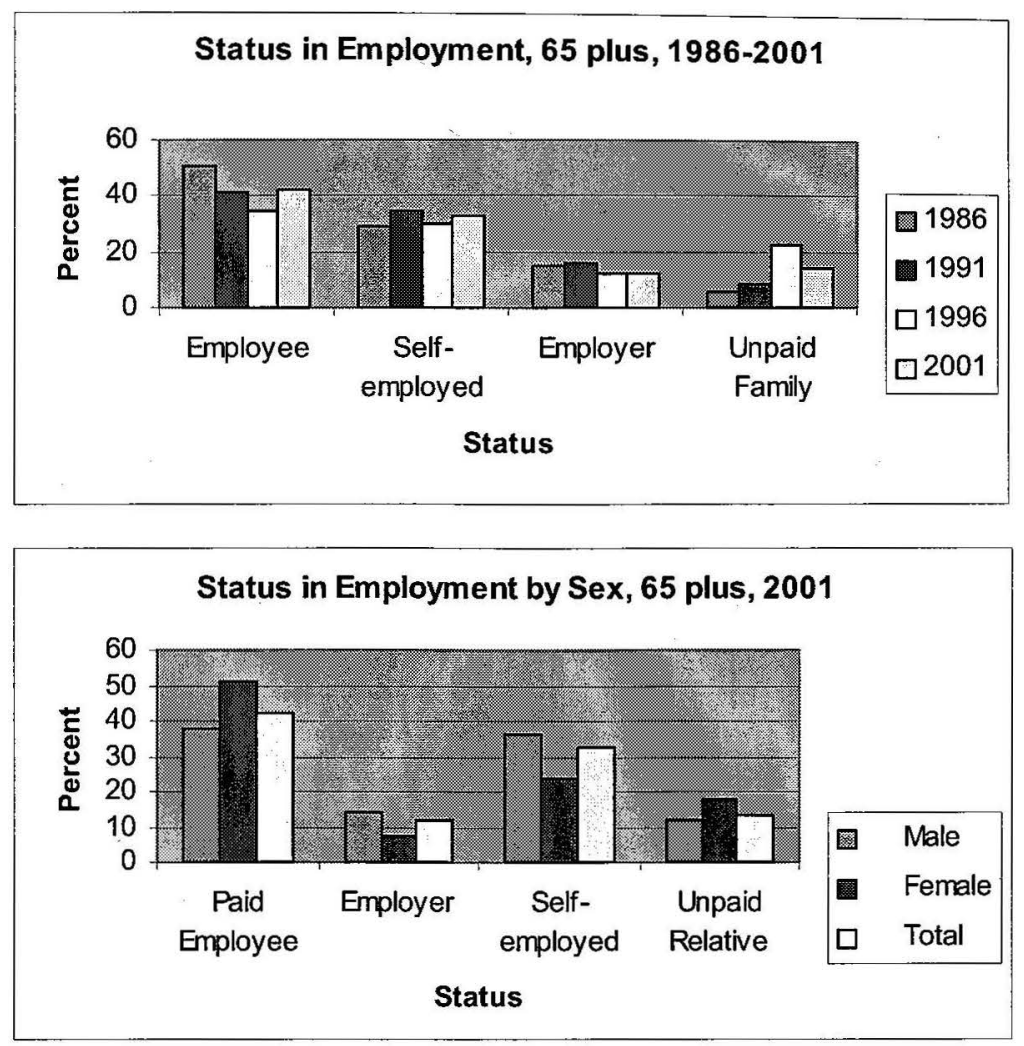

\section{Occupation trends}

While occupations in the agriculture and fisheries occupation group still account for almost a quarter of employment for the over 65 group, the significance of the group is declining. Most of the people employed in these occupations are farmers of one type or another.
All other occupations have experienced small rises in the proportion of older people employed, with the biggest percentage point change over the twenty year period since 1991 (2.6 percentage points) being in the plant machine operators and assemblers. However, this occupation group has under 3,000 people aged 65 and over, and is the second smallest for people 65 and over.

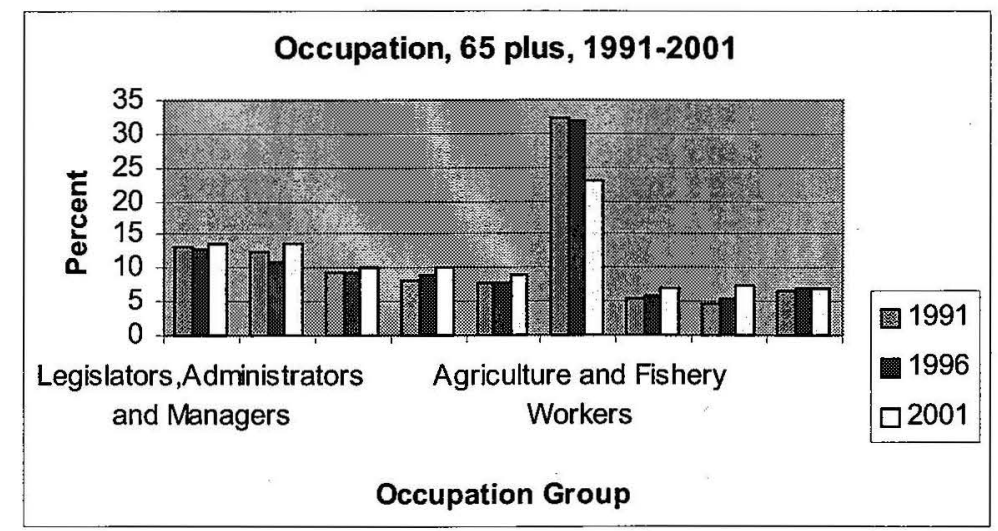

The type of work people aged 65 and over do is determined by a number of factors. The physical demands of some jobs mean few older people work in them. There are no older people working as metal drawers and extruders, or paper pulp preparation plant operators, for example.
Other jobs require quick reactions and concentration which tend to deteriorate with age, and it is not surprising that there are no people over 65 working as Air Traffic Controllers. 
Yet other jobs are products of new technology and new skills that people in this age group never had the opportunity to be involved in - for example only 99 of the 19,308 computing professionals are 65 and over.
Some occupations encourage early retirement eg police and fire service, where only tiny numbers of people aged 65 and over are employed; and yet other occupations are characterised by a youth culture, like waiters and bar tenders, where 354 out of 42,387 are older workers.

Top ten occupations for people aged 65 years and over in 2001

\begin{tabular}{|l|r|}
\hline Occupation (4 digit level) & $\begin{array}{c}\text { Number } \\
\text { employed } \\
\text { in 2001 }\end{array}$ \\
\hline Livestock Producers & 3,387 \\
\hline Crop and Livestock Producers & 2,310 \\
\hline General Managers & 1,761 \\
\hline Supply and Distribution Managers & 1,704 \\
\hline Salespersons and Demonstrators & 1,452 \\
\hline Caretakers and Cleaners & 1,404 \\
\hline Gardeners and Nursery Growers & 1,254 \\
\hline Office Clerks & 1,227 \\
\hline Fruit Growers & 879 \\
\hline Personal Care Workers & 804 \\
\hline Total Employment in Top Ten Occupations & 16,182 \\
\hline Total Specified Occupation & 39,585 \\
\hline
\end{tabular}

Employment in ten occupations accounted for about 41 percent of the total number of employed people aged 65 and over who specified an occupation at the 2001 census. The same occupations account for around 26 percent of employment among people aged under 65 years.

As the earlier graph indicated, agricultural occupations are most common type of job for this employed people aged 65 and over. Many older people work as managers and the third and fourth most popular occupations are of this type

The top occupation for women aged 65 and over is "salespersons and demonstrators", with 732 employees. Two occupations are second equal in size with 723 workers - "office clerks" and "personal care workers".

Top 5 occupations by selected qualification, 2001 census

\begin{tabular}{|c|c|c|}
\hline & Description & Number \\
\hline \multirow[t]{5}{*}{ No qualification } & Livestock producers & 1488 \\
\hline & Crop and livestock producers & 993 \\
\hline & Caretakers and cleaners & 612 \\
\hline & Supply and distribution managers & 525 \\
\hline & Salespersons and demonstrators & 516 \\
\hline \multirow[t]{5}{*}{ Vocational qualification } & Livestock producers & 345 \\
\hline & Nursing and midwifery & 309 \\
\hline & General managers & 297 \\
\hline & Primary teaching & 288 \\
\hline & Crop and livestock producers & 264 \\
\hline \multirow[t]{5}{*}{ Degree } & Accountants & 390 \\
\hline & Medical doctors & 327 \\
\hline & Barristers and Solicitors & 231 \\
\hline & General Managers & 219 \\
\hline & Tertiary Teachers & 159 \\
\hline
\end{tabular}


Older employed people with no qualification have very similar top five occupations to the total population; older people with a vocational qualification are more likely to be in nursing or primary teaching; and older people with a degree are more likely to be accountants and medical doctors.
Occupation of older people also varies by ethnicity, with figures from the 2001 census showing that older Maori are more likely to be caretakers or cleaners, and primary or early childhood teaching professionals.

\section{Ten occupations with significant numbers of older people}

\begin{tabular}{|l|r|r|r|}
\hline & $\begin{array}{c}\text { No } \\
\text { Employed 65 } \\
\text { plus }\end{array}$ & $\begin{array}{c}\text { Total } \\
\text { Number } \\
\text { Employed }\end{array}$ & $\begin{array}{c}\text { Percent 65 } \\
\text { plus }\end{array}$ \\
\hline Legislators & 147 & 702 & 21 \\
\hline Musical Instrument Makers and Tuners & 30 & 162 & 19 \\
\hline Judges & 36 & 270 & 13 \\
\hline Composers, Musicians and Singers & 390 & 3789 & 10 \\
\hline Mixed Livestock Producers & 486 & 4884 & 10 \\
\hline Bus Drivers & 456 & 4896 & 9 \\
\hline Crop and Livestock Producers & 2310 & 25917 & 9 \\
\hline Religious Professionals & 285 & 3492 & 8 \\
\hline Livestock Producers & 3387 & 43029 & 8 \\
\hline Sculptors, Painters and Related Artists & 204 & 2670 & 8 \\
\hline
\end{tabular}

Some occupations have a reasonable concentration of people aged 65 and over. Twenty one percent of legislators are 65 plus, followed by almost 19 percent of musical instrument makers and tuners and 13 percent of Judges, whereas people aged 65 and over make up just 3 percent of total employment.

\section{Full-time/Part-time Employment}

Between 1986 and 1996 part-time employment among people aged 65 and over grew by nearly 20 percent and doubled between 1991 and 1996, but between 1996 and 2001 full-time employment outstripped part-time growth (up 45 percent and 27 percent respectively).

The majority ( 53 percent) of the 49,935 people over 65 who were employed in 2001, reported working part-time. Over half of men still working after age 64 are working full-time, compared to about one third of women.

Overall, older employed people work about ten hours per week less on average than their younger counterparts.

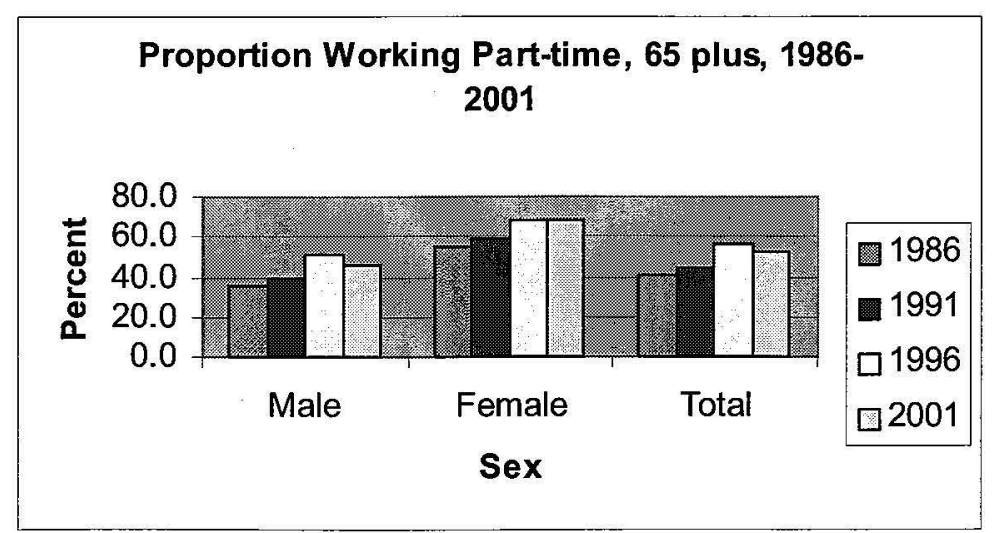




\section{Industry}

Employment of older people is concentrated in the services and primary sectors.

There have been small changes since 1986 in the employment of older people across industrial sectors. Employment in the primary sector has dropped from a high of 33.5 percent in 1991 to 25.4 percent in 2001 . Similarly employment in the secondary sector has dropped from 17 percent in 1986 to 14 percent in 2001. The gains have been in the services sector, rising from
54.8 percent of older people's employment in 1986 to 61.1 percent in 2001.

For males the predominant industry group within the services sector was Property and Business Services, accounting for 14.2 percent of 65 and over male employment.

For older females the predominant industry group within the services sector was the Health and Community Services industry group.

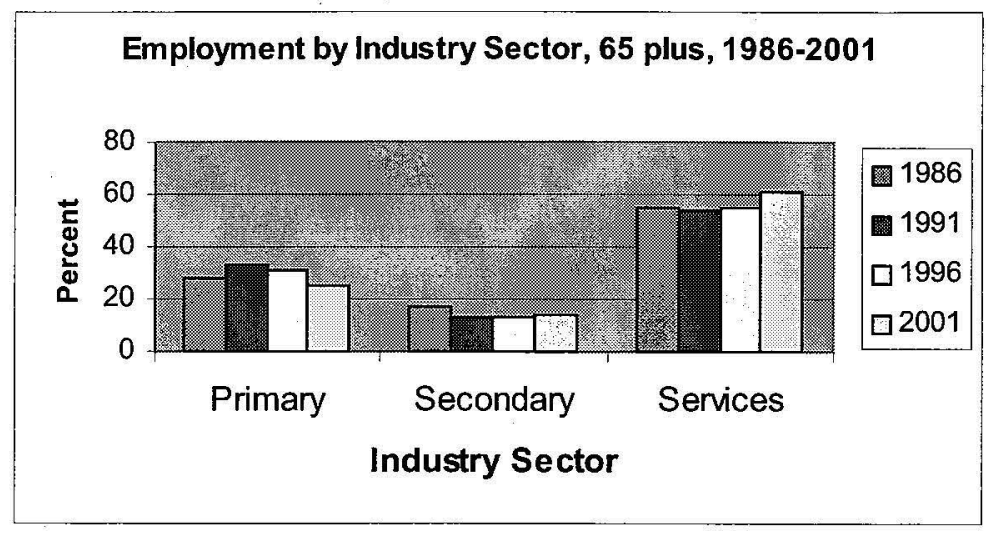

\section{Earnings}

As can be seen in the table below, earnings are a relatively small part of the average older people's weekly income.

In the Survey of Older People in 2000, approximately 42 percent of respondents had contributed to a private or job-related superannuation scheme, and over 80 percent of this group had received contributions from an employer.
In the Survey of Older People, the median income for single respondents was $\$ 12,090$ and the median for couples was $\$ 21,000$.

The survey also showed that the distribution of income in the 65 and over group is very skewed to the left, with 90 percent of single respondents earning below $\$ 23,000$ per annum and 90 percent of couples reporting incomes below $\$ 53,300$.

\section{Average Weekly Income for All People aged 65 years and Over for years 1997 to 2002}

\begin{tabular}{|c|c|c|c|c|c|c|c|}
\hline & \multicolumn{6}{|c|}{ Average Weekly Income from } & \multirow[b]{2}{*}{$\begin{array}{c}\text { Number of } \\
\text { People }^{(1)}\end{array}$} \\
\hline & $\begin{array}{c}\text { Wages and } \\
\text { Salaries }\end{array}$ & \begin{tabular}{c|} 
Self- \\
employment
\end{tabular} & $\begin{array}{c}\text { Government } \\
\text { Transfers }\end{array}$ & Investments & $\begin{array}{c}\text { Other } \\
\text { Transfers }\end{array}$ & $\begin{array}{c}\text { All Sources } \\
\text { Collected }\end{array}$ & \\
\hline & \multicolumn{6}{|c|}{$(\$)$} & $(000)$ \\
\hline June 1997 & 16 & 15 & 245 & .. & 21 & 295 & 407.0 \\
\hline June 1998 & 8 & 13 & 221 & .. & 25 & 267 & 412.6 \\
\hline June 1999 & 13 & 13 & 221 & .. & 22 & 268 & 417.5 \\
\hline June 2000 & 12 & 20 & 235 & .. & 22 & 289 & 422.7 \\
\hline June 2001 & 16 & 15 & 245 & .. & 21 & 295 & 428.9 \\
\hline June 2002 & 22 & 19 & 251 & - & 24 & 315 & 435.3 \\
\hline
\end{tabular}

Source: New Zealand Income Survey 


\section{Unpaid Work}

About half of people aged 65 and over (52 percent) do some form of unpaid work for people who did not live in the same household as respondents.

The most common type of unpaid work overall comprised attending a committee meeting, organising, doing administration or policy work. Twenty one percent did this type of work, and it was also the most popular unpaid work for males ( 24 percent of males participated).
The second most common type of unpaid work for older people was minding a child who did not live in the same household as the respondent ( 21 percent of people aged 65 and over did this type of work), and it was the most popular type of unpaid work carried out by females (21.8 percent of females participated).

Overall, males aged 65 and over did more unpaid work outside the home than females of the same age. Fifty five percent of males and 49.5 percent of females did this sort of work.

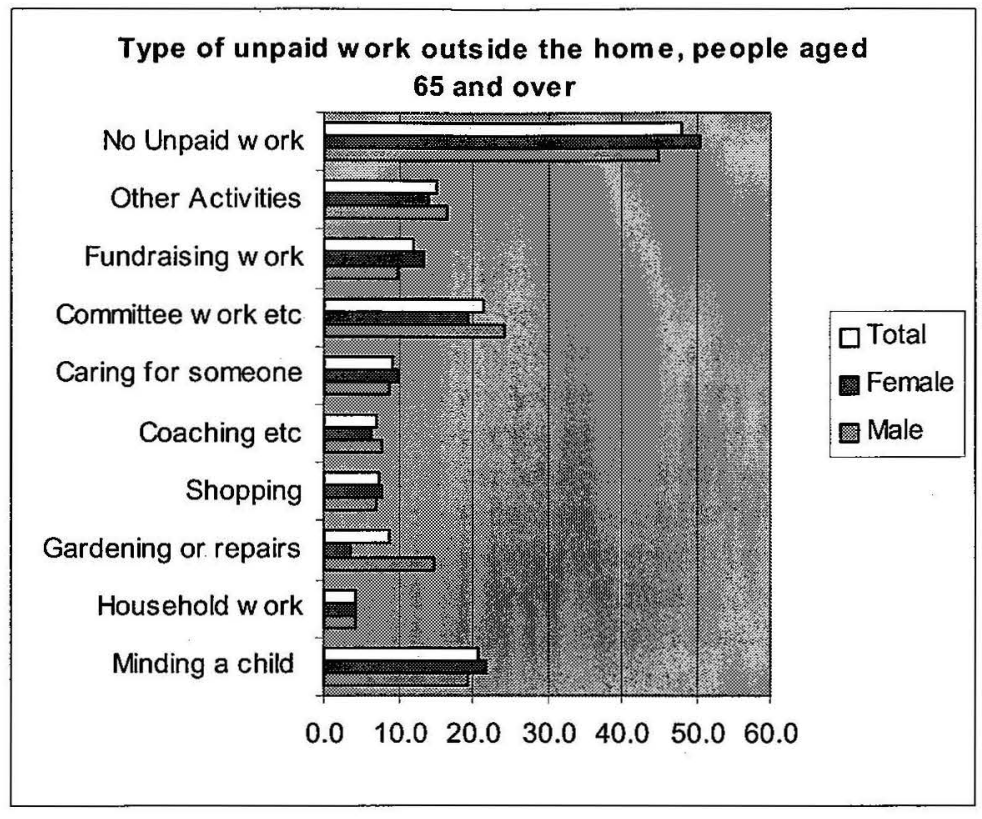

Source: Survey of Older People in 2000

\section{Hours of Unpaid Work in Last 4 Weeks}

Almost two thirds (63 percent) of people aged 65 and over who did unpaid work for people who did not live with them did less than 15 hours of work in the 4 weeks prior to the interview date.

However, nearly 10 percent of respondents reported doing 60 hours or more of unpaid work.

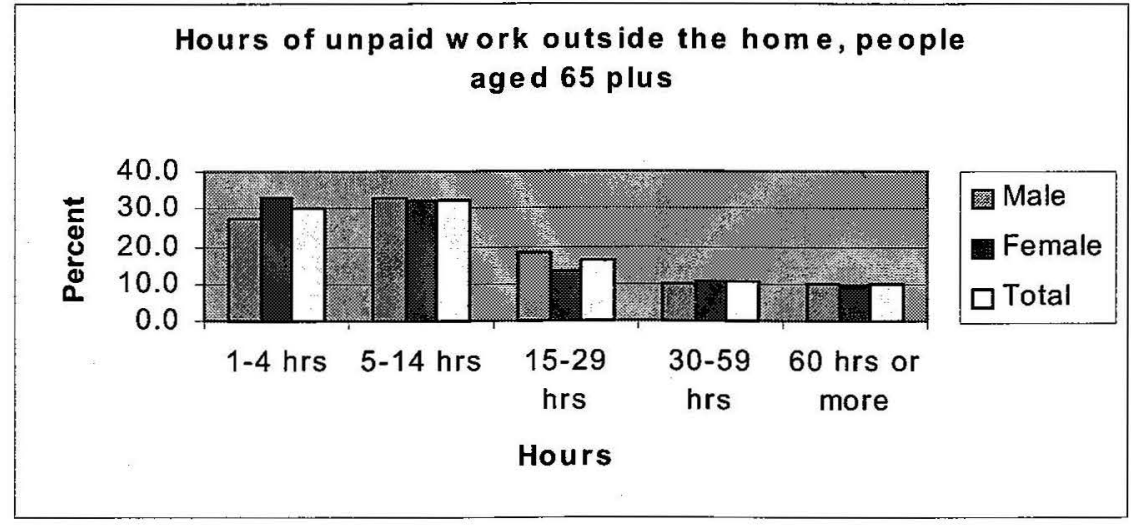

Source: Survey of Older People in 2000 